\title{
Resenha do livro Estado e Gestão Pública: Visões do Brasil Contemporâneo
}

\author{
Oswaldo Munteal *
}

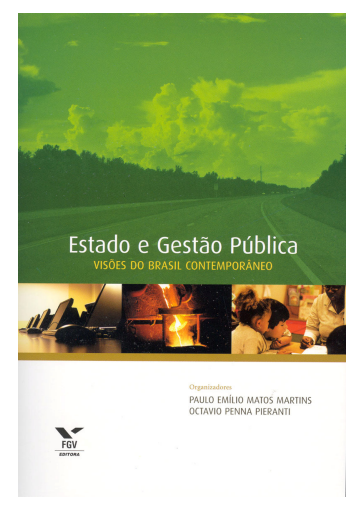

MARTINS, Paulo Emílio Matos e Octavio Penna Pieranti (Org.) Estado e Gestão

Pública: Visões do Brasil Contemporâneo. Rio de Janeiro: Editora FGV, 2006,

$2^{\text {a }}$ edição. 340 p.

Em primeiro lugar, cabe ressaltar que o debate sobre o Estado perdeu o impacto no meio acadêmico, e a capacidade de sensibilizar o cidadão. Afinal para que serve o Estado? A mídia hegemônica nos bombardeia diariamente com afirmações de que o Estado dá prejuízo, é corrupto e não gera bem-estar social. O que fica esquecido é a natureza de classe deste Estado contemporâneo no Brasil e na América Latina. Os compromissos assumidos pelas elites dirigentes da periferia das Américas pouco ou nada têm a ver com a missão do Estado. Marx dizia: "O Estado é um mal necessário". A conquista do poder depende, em larga escala, do controle do poder público pelos agentes da sociedade organizada. Mas é necessário, também, que o Estado assuma as responsabilidades de condução e da definição de uma nova agenda, em substituição àquela deteriorada após décadas de ditadura e de um liberalismo predatório.

Os organizadores do livro Estado e Gestão Pública: Visões do Brasil Contemporâneo estão de parabéns pela ousadia de retomar a discussão e fazer desta coletânea uma obra articulada em suas partes, e com uma espinha dorsal clara e definida. O núcleo do livro refere-se às estratégias de desenvolvimento econômico e social. Podese dividi-lo em três grandes unidades para reflexão: 1 - aspectos estruturais do desenvolvimento econômico latino-americano; 2 - reforma do Estado e administração pública; 3 - a crise de gestão do setor público.

Foi criado um falso laissez-faire na América Latina, como bem registra Theotonio dos Santos no primeiro estudo: "O golpe de Estado de 1964 no Brasil entregou o poder aos monetaristas com o objetivo de assegurar a estabilidade monetária, contra a proposta estruturalista de ampliar os mercados nacionais pela via da reforma agrária e outras reformas capazes de distribuir a renda e ampliar o consumo." Com base nesta dobra, o livro avança na direção de uma retomada do desenvolvimento em bases políticas. A produção do crescimento oblitera o social e, cada vez mais, favorece o enfoque monetarista que prevalece nos cursos de Economia e Administração nas nossas principais escolas superiores.

Os professores Paulo Emílio Matos Martins e Octavio Penna Pieranti ofereceram ao leitor acadêmico e ao público em geral um livro de referência para os estudos de economia política. O texto de Carlos Eduardo Martins encerra a primeira unidade abordando aspectos mais globais do desenvolvimento capitalista e os limites próprios deste modelo de gestão. Neste estudo deve-se referenciar a originalidade e erudição do pesquisador, que garimpa antigos autores e teses consideradas ultrapassadas, dando-lhes uma dimensão explicativa rara. Hoje,

"Doutorado em História Social pela Universidade Federal do Rio de Janeiro - UFRJ. Professor de História Contemporânea da UERJ, PUC-Rio e FACHA e Coordenador do Programa de Estudos de Conjuntura Brasileira-Reitoria/UERJ. Cursando estágio de Pós-Doutorado na EBAPE/FGV. Endereço: Praia de Botafogo, 190 - sala 515 - Botafogo - Rio de Janeiro/RJ - Brasil - CEP: 22250-900. E-mail: munteal@gbl.com.br. 
em práticas das Ciências Humanas e Sociais, o raciocínio a partir de marcos temporais de longa duração são escassos. O texto de Carlos Eduardo é caudaloso sem perder a precisão, rico em dados históricos e, sobretudo, a intenção inicial se cumpre, quando o autor estabelece relações coerentes entre o passado e o presente da acumulação de capitais.

A partir do estudo de Sonia Fleury, passando pelos trabalhos de Fernando Tenório e Enrique Saraiva, Frederico Lustosa, Alketa Peci, José Antônio Puppim e José Cezar Castanhar, podem-se verificar um segundo momento do livro em torno da reforma do Estado brasileiro e os impasses de uma modernização que priorizou a privatização. A obra ganha ainda mais fôlego, quando entra no debate acerca das visões sobre o Brasil contemporâneo. Esse é mais um desafio deste trabalho coletivo, que recupera o Brasil como um problema para as Ciências Sociais.

Os referenciais teóricos dos autores são diversos, o que torna o livro atraente, plural metodologicamente e acessível também ao leitor das mais diversas áreas das Ciências Humanas. "Estado e Gestão Pública: Visões do Brasil Contemporâneo", nesta segunda parte, oferece uma ferramenta fundamental para o trabalho docente na graduação e na pós-graduação em Administração Pública.

A unidade que fecha o livro destaca, nos estudos de Marco Aurélio Ruediger, Luiz Antonio Joia, Bianor Scelza Cavalcanti, Octavio Penna Pieranti e Deborah Moraes Zouain e Armando Cunha, as ações tópicas e os problemas mais específicos da gestão pública. Alguns gargalos devem ser ressaltados, como, por exemplo, a informação, a educação, a liberdade de imprensa e a inclusão digital. A gestão pública tem, assim, uma obra de referência para o estudo das assimetrias regionais, sobre a dinâmica das empresas públicas e privadas e sobre o papel da governança na era da globalização.

Os professores Paulo Emílio Matos Martins e Octavio Penna Pieranti oferecem ao leitor brasileiro uma revisão dos estudos da Administração à luz de um tempo nublado, em que sopram novos ventos 